\title{
No depth-dependence of fine root litter decomposition in temperate beech forest soils
}

\author{
Emily F. Solly • Ingo Schöning • Nadine Herold • \\ Susan E. Trumbore $\cdot$ Marion Schrumpf
}

Received: 29 September 2014 / Accepted: 22 April 2015 /Published online: 4 May 2015

(C) Springer International Publishing Switzerland 2015

\begin{abstract}
Aims Subsoil organic carbon (OC) tends to be older and is presumed to be more stable than topsoil OC, but the reasons for this are not yet resolved. One hypothesis is that decomposition rates decrease with increasing soil depth. We tested whether decomposition rates of beech fine root litter varied with depth for a range of soils using a litterbag experiment in German beech forest plots.

Methods In three study regions (Schorfheide-Chorin, Hainich-Dün and Schwäbische-Alb), we buried 432 litterbags containing $0.5 \mathrm{~g}$ of standardized beech root material (fine roots with a similar chemical composition collected from 2 year old Fagus sylvatica L. saplings, root diameter $<2 \mathrm{~mm})$ at three different soil depths $(5,20$ and $35 \mathrm{~cm})$. The decomposition rates as well as the changes in the carbon $(\mathrm{C})$ and nitrogen $(\mathrm{N})$ concentrations of the decomposing fine root litter were determined at a 6 months interval during a 2 years field experiment.
\end{abstract}

Responsible Editor: Kees Jan van Groenigen.

Electronic supplementary material The online version of this article (doi:10.1007/s11104-015-2492-7) contains supplementary material, which is available to authorized users.

E. F. Solly $\cdot$ I. Schöning $\cdot$ N. Herold $\cdot$ S. E. Trumbore $•$

M. Schrumpf

Max Planck Institute for Biogeochemistry, Hans-Knöll-Str.

10, 07745 Jena, Germany

E. F. Solly $(\bowtie)$

Swiss Federal Institute for Forest, Snow and Landscape

Research WSL, Birmensdorf, Switzerland

e-mail: emily.solly@wsl.ch
Results The amount of root litter remaining after 2 years of field incubation differed between the study regions (76 $2 \%$ in Schorfheide-Chorin, $85 \pm 2 \%$ in Schwäbische-Alb, and $88 \pm 2 \%$ in Hainich-Dün) but did not vary with soil depth.

Conclusions Our results indicate that the initial fine root decomposition rates are more influenced by regional scale differences in environmental conditions including climate and soil parent material, than by changes in microbial activities with soil depth. Moreover, they suggest that a similar potential to decompose new resources in the form of root litter exists in both surface and deep soils.

Keywords Fagus sylvatica $L \cdot$ Root litter . Decomposition $\cdot$ Soil depth $\cdot$ Beech forests

\section{Introduction}

Forests cover approximately $30 \%$ of the global land surface and forest soils contain up to $40 \%$ of the total belowground terrestrial $\mathrm{C}$, including soil organic matter, litter and living roots (Brunner and Godbold 2007; Dixon et al. 1994). Roots are a major source supplying $\mathrm{C}$ to soil organic matter, the largest reservoir of the terrestrial C cycle (Mendez-Millan et al. 2010; Rasse et al. 2005; Schlesinger 1997). The organic compounds contained in dead roots are transformed by decomposition and are partly converted to stable forms of soil organic matter or are being mineralized (Trumbore 2009). Root decomposition controls on the dynamics 
of soil OC storage involve complex interactions between plants and the soil biota as well as their reactions to changes in local environmental conditions such as climate, soil parent material, $\mathrm{pH}$ and nutrient availability (Chen et al. 2000; Handa et al. 2014; Solly et al. 2014, Thoms et al. 2010). Although edaphic conditions vary with depth in a soil profile and more than half of total soil OC is found in subsoils (Jobbágy and Jackson 2000; Rumpel and Kögel-Knabner 2011), the majority of the studies on root litter decomposition and $\mathrm{C}$ dynamics have focused on topsoils (Heim and Frey 2004; Hobbie et al. 2010; Sun et al. 2013; van Huysen et al. 2013). Accordingly, the pattern of root decomposition in the deeper soil layers and its controlling factors remain poorly understood (Gill and Burke 2002; Rumpel and Kögel-Knabner 2011). Moreover, the lack of large scale studies on root decomposition at different soil depths inhibits our ability to determine how soil OC storage will respond to short and long term environmental changes in different regions. Even small variations of decomposition rates of plant litter in forest ecosystems could influence the OC concentrations and storage of the large soil $\mathrm{C}$ reservoir (Trumbore 2009).

While OC concentrations are higher in the topsoil, due to higher plant inputs, root densities, microbial biomass and substrate input through litter leaching, the age of soil OC increases with depth in most ecosystems (Paul et al. 1997; Trumbore 2000). One possible explanation for older subsoil OC is a reduction in OC turnover with depth, which is supported by increasing portions of mineral-protected OC, changes in the quantity and quality of plant litter input and lower seasonal variations in soil water content and soil temperature in deeper compared to surface soil, all altering microbial activity and root decomposition rates (Fierer et al. 2003a; Fontaine et al. 2007; Rovira and Ramón Vallejo 2002; Rumpel and Kögel-Knabner 2011). Interestingly, the age of the free light fraction of soil organic matter, representing the $\mathrm{C}$ not protected inside aggregates or associated with minerals, does not show a consistent increase with depth (Schöning and Kögel-Knabner 2006; Schrumpf et al. 2013). This suggests that C mineral protection is more important for decreasing subsoil OC turnover than an overall reduced potential for microbial decomposition. However, until now little effort was done to determine whether greater $\mathrm{C}$ stability and reduced microbial activity with soil depth influence organic matter decomposition rates (Gill and Burke 2002; Sanaullah et al. 2011).

In temperate forest topsoils, fine root decomposition rates have been observed to vary regionally and with changes in environmental conditions such as soil temperature and moisture (Solly et al. 2014), which in turn influence the relative activities of the decomposer community (Chen et al. 2000). But it is still unclear whether the same pattern will be observed in deeper soil layers and whether decomposition shows a similar dependence on depth in different soil types. The vast majority of decomposition studies have until now been conducted at small scales and using on-site specific litter, complicating site and regional inter-comparison (Parton et al. 2007). Hence, here we used a standardized fine root litter, with similar chemical quality, to determine controls of fine root decomposition in 12 beech (Fagus sylvatica $L$.) forest plots.

The main objective of this study is to assess the depth-dependence of fine root litter decomposition for a range of forest soils distributed over three German study regions that differ in climate and soil parent material. We used the litterbag method to estimate decomposition rates of standardized beech fine root litter. Our hypotheses are that i) the rate of root decomposition decreases with increasing soil depth, reflecting changes in soil abiotic and biotic conditions; and that ii) the decomposition rates differ between the three study regions for all studied depths, mainly due to diverse and site-specific climate and soil biota, with faster decomposition in warmer and moister not waterlogged sites.

\section{Materials and methods}

\section{Study sites}

We conducted this study in 12 forest plots dominated by European beech (Fagus sylvatica L.,) and distributed in three German regions of the 'Biodiversity Exploratories' (Fischer et al. 2010). The Schwäbische Alb is situated in south-western Germany, the Hainich-Dün in central Germany and the Schorfheide-Chorin in northeastern Germany. These three study regions differ in climate and soil parent material (Table 1; for details see Fischer et al. (2010)). For each region we selected four forest plots $(100 \mathrm{~m} \times 100 \mathrm{~m})$ with similar age class management. All forests were harvested at 80-120 year intervals and were in an old timber development stage. 
Table 1 Main geographical and environmental characteristics of the three study regions: Schwäbische Alb, Hainich-Dün, SchorfheideChorin (adapted from Fischer et al., 2010)

\begin{tabular}{|c|c|c|c|}
\hline & Schwäbische Alb & Hainich-Dün & Schorfheide-Chorin \\
\hline Location & SW Germany & Central Germany & NE Germany \\
\hline Coordinates & $\mathrm{N} 48^{\circ} 26^{\prime} \mathrm{E} 9^{\circ} 23^{\prime}$ & $\mathrm{N} 51^{\circ} 9^{\prime} \mathrm{E} 10^{\circ} 28^{\prime}$ & $\mathrm{N} 53^{\circ} 0^{\prime} \mathrm{E} 13^{\circ} 46^{\prime}$ \\
\hline Area of the region $\left[\mathrm{km}^{2}\right]$ & $\sim 422$ & $\sim 1300$ & $\sim 1300$ \\
\hline Soil type & Cambisol (eutric) & Luvisol & Cambisol (dystric) \\
\hline Altitude a.s.1 [m]. & $460-860$ & $285-550$ & $3-140$ \\
\hline Mean annual temperature $\left[{ }^{\circ} \mathrm{C}\right]$ & $6.0-7.0$ & $6.5-8.0$ & $8.0-8.5$ \\
\hline Mean annual precipitation [mm] & $700-1000$ & $500-800$ & $500-600$ \\
\hline Parent material & Jurassic limestone & $\begin{array}{l}\text { Triassic shell limestone } \\
\text { and loess }\end{array}$ & $\begin{array}{l}\text { Glacial till and aeolian / fluvial } \\
\text { sand in depressions }\end{array}$ \\
\hline
\end{tabular}

\section{Soil properties}

To evaluate the soil $\mathrm{OC}$ and total $\mathrm{N}$ concentrations and stocks, we collected one mineral soil core in each of the forest plots (For more details see: Grüneberg et al. 2010). We used a soil corer with an inner diameter of 8.3 and a length of $110 \mathrm{~cm}$ (Eijkelkamp Agrisearch Equipment BV, Giesbeek, The Netherlands). The core was driven into the soil with a motor hammer (Atlas Copco AB, Nacka, Sweden). Organic layers were removed before coring. We sectioned the soil cores into increments $(0-10,10-30$ and $30-50 \mathrm{~cm})$ for analysis. Prior to processing, the soil samples were air dried at $20{ }^{\circ} \mathrm{C}$ to constant weight and sieved to $<2 \mathrm{~mm}$. Roots were air dried and their weight was determined.

Sieved soil subsamples were ground in a ball mill (RETSCH MM300, Retsch, Haan, Germany). Total C and $\mathrm{N}$ concentrations were determined by dry combustion in an elemental analyser (VarioMax, Hanau, Germany). To calculate the concentration of $\mathrm{OC}$ in each soil sample we determined the amount of inorganic $\mathrm{C}$ by removing all $\mathrm{OC}$ at a temperature of $550{ }^{\circ} \mathrm{C}$ for $5 \mathrm{~h}$ (Heiri et al. 2001), and subtracted this value from the total $\mathrm{C}$ concentrations. $\mathrm{C}$ and $\mathrm{N}$ stocks of the soil samples were calculated from the OC and total $\mathrm{N}$ concentrations of the soils and the dry weight of the sieved soil samples.

Soil temperature and soil moisture were measured continuously from 10 meteorological stations in the same study region every $30 \mathrm{~min}$ with ground surface temperature sensors (Meier NT Type 2021, Zwönitz, Germany, installed at 10, 20 and $50 \mathrm{~cm}$ belowground) and soil humidity probes (DeltaT ML2X, Cambridge, UK, installed at 10 and $20 \mathrm{~cm}$ ). In this study, we used the yearly averages of soil temperature and volumetric soil moisture for the two consecutive years of root decomposition. We also calculated the number of days during which the soil was frozen $\left(\leq 0^{\circ} \mathrm{C}\right)$.

\section{Chemical composition of fine roots}

To determine the homogeneity of the initial quality of the standardized root litter (fine roots with a similar chemical composition collected from 2 year old Fagus sylvatica L. saplings, root diameter $<2 \mathrm{~mm}$ ), subsamples were ground in a ball mill (RETSCH MM200, Retsch, Haan, Germany). Total $\mathrm{C}$ and $\mathrm{N}$ concentrations were determined using the elemental analyzer (Vario EL, Elementar, Hanau, Germany). Concentrations of calcium $(\mathrm{Ca})$, magnesium $(\mathrm{Mg})$, aluminium $(\mathrm{Al})$ and phosphorous $(\mathrm{P})$ were measured using inductively coupled plasma - optical emission spectrometry (ICP-OES, Optima 3300 DV, Perkin Elmer, Norwalk, USA) (for details on the method see: Raessler et al. 2005). Lignin and cellulose content were estimated from thermogravimetric analysis in Argon atmosphere (TGA / SDTA851 ${ }^{\mathrm{e}}$ Mettler Toledo, GmbH, Giessen, Germany) (Yang et al. 2005, method described in Solly et al. 2014).

\section{Root decomposition}

We assessed the decomposition rates of beech fine root litter buried at three depths. To provide a nearly homogeneous substrate for decomposition, we used fine roots collected from 2 years old beech saplings grown in sand. While there may be some chemical differences between deep and shallow fine roots, as well as between roots of different diameter size and age, our aim was to focus on 
the effect of soil depth on fine root decomposition rather than on the differences triggered by plant allocation patterns.

After removing the mineral soil particles attached to the fine roots of the saplings, by carefully cleaning the roots with distilled water in a $63 \mu \mathrm{m}$ sieve, we separated the fine roots $(<2 \mathrm{~mm}$ diameter) from the coarse roots and dried all samples at $40{ }^{\circ} \mathrm{C}$ to constant weight in a forced-air oven. For details on the method see Solly et al. (2014).

We prepared 432 litterbags by placing $0.5 \pm 0.01 \mathrm{~g}$ of dry fine root litter into a $10 \mathrm{~cm} \times 10 \mathrm{~cm}$ litterbag made of a $100 \mu \mathrm{m}$ polyester mesh screening to allow microfaunal decomposition (Schwegmann Filtrations-Technik $\mathrm{GmbH}$, Grafschaft-Gelsdorf, Germany). We individually labelled each litterbag with a stainless steel label that was placed inside the enclosure and measured the total mass of each litterbag. We buried 36 litterbags $(n=12$ at three depths) in each of the 12 forest plots in October 2011. After extracting 12 intact soil cores $(48 \mathrm{~mm}$ diameter, $40 \mathrm{~cm}$ depth) from each forest plot, we placed the litterbags vertically, adhering to the lateral surface of the soil core hole, at average soil depths of 5, 20 and $35 \mathrm{~cm}$. To backfill the space between the litterbags we used the soil extracted from the core, which we cut at the specific depths. In April 2012, October 2012, April 2013 and October 2013 we collected three litterbags from each soil depth in every forest plot $(n=9$ per collection date in each site). The collected litterbags were transported to the laboratory where we gently removed the fine roots and hyphae grown around the litterbags as well as soil particles adhering to the fine root-litter. After drying at $40{ }^{\circ} \mathrm{C}$ we calculated the fine root decomposition rates (mass recovery in $\%$ ) for each forest plot as the average amount of mass recovered in the three litterbags collected at each collection date. We further estimated the fine root litter decomposition rates ( $k$-values) for every soil depth in all forest plots by fitting the exponential function

$X_{t}=X_{0} e^{-k t}$

to the decomposition values of the whole time series (Olson 1963). Where $X_{t}$ is the amount of fine root remaining at time $t$ and $X_{0}$ is the initial root mass at time 0 . After 2 years of decomposition, three replicates per soil depth were analyzed for total $\mathrm{C}$ and $\mathrm{N}$ concentrations.
Statistics

We conducted statistical analyses with $\mathrm{R}$, version 3.0.2 (R Development Core Team 2013). Throughout the manuscript we present data as means \pm standard deviation. Analysis of variance (ANOVA) accompanied by Tukey-Kramer HSD test was used to examine statistical differences of the fine root mass remaining, the root biomass, the $\mathrm{OC}$ and total $\mathrm{N}$ concentrations and stocks in the different study regions and at the different soil depths. ANOVA analysis was also used to detect significant differences between the $\mathrm{C}: \mathrm{N}$ ratio, $\mathrm{C}$ and $\mathrm{N}$ concentrations of the decomposing fine root litter at different soil depths. Significant changes in the C:N ratio, C and $\mathrm{N}$ concentrations between the initial standardized fine root litter and the root litter after 2 years of decomposition (averaged at all soil depths) were tested with Student's $t$ test. Normal distribution of residuals and homogenous variances were checked before statistical analysis. The chosen $\mathrm{p}$-value for detecting statistical differences was $p<0.05$.

\section{Results}

Soil properties and root biomass

OC concentrations ranged between 12 and $42 \mathrm{~g} \mathrm{~kg}^{-1}$ in the soil sampled at $0-10 \mathrm{~cm}$ depth. These were significantly higher than the concentrations found at $30-50 \mathrm{~cm}$ belowground, which ranged between 2 and $11 \mathrm{~g} \mathrm{~kg}^{-1}$. Total $\mathrm{N}$ concentrations also declined significantly with depth (Table 2). OC and total $\mathrm{N}$ concentrations were highest in the Schwäbische-Alb, followed by HainichDün and Schorfheide-Chorin. The amount of root biomass (dead and live) extracted from soils as well as OC and total $\mathrm{N}$ stocks decreased with depth in all study regions (Table 2). Variability in the chemical quality of roots $(\mathrm{C}, \mathrm{N}, \mathrm{Ca}, \mathrm{Mg}, \mathrm{Al}, \mathrm{P}$, lignin and cellulose) found in the beech fine root biomass that we used for our decomposition experiment was minor (Table 2 ). The variability of soil moisture and soil temperature declined with depth for all study regions (Table 3). The soils of the Schwäbische-Alb study region had a similar volumetric soil water content (ranging between 20 and $38 \%$ ) to the ones in the Hainich-Dün (ranging between 22 and $31 \%$ ) and a higher volumetric soil water content than the soils in the Schorfheide-Chorin (ranging between 9 and $20 \%$ ). The topsoil in the Hainich-Dün was frozen for 


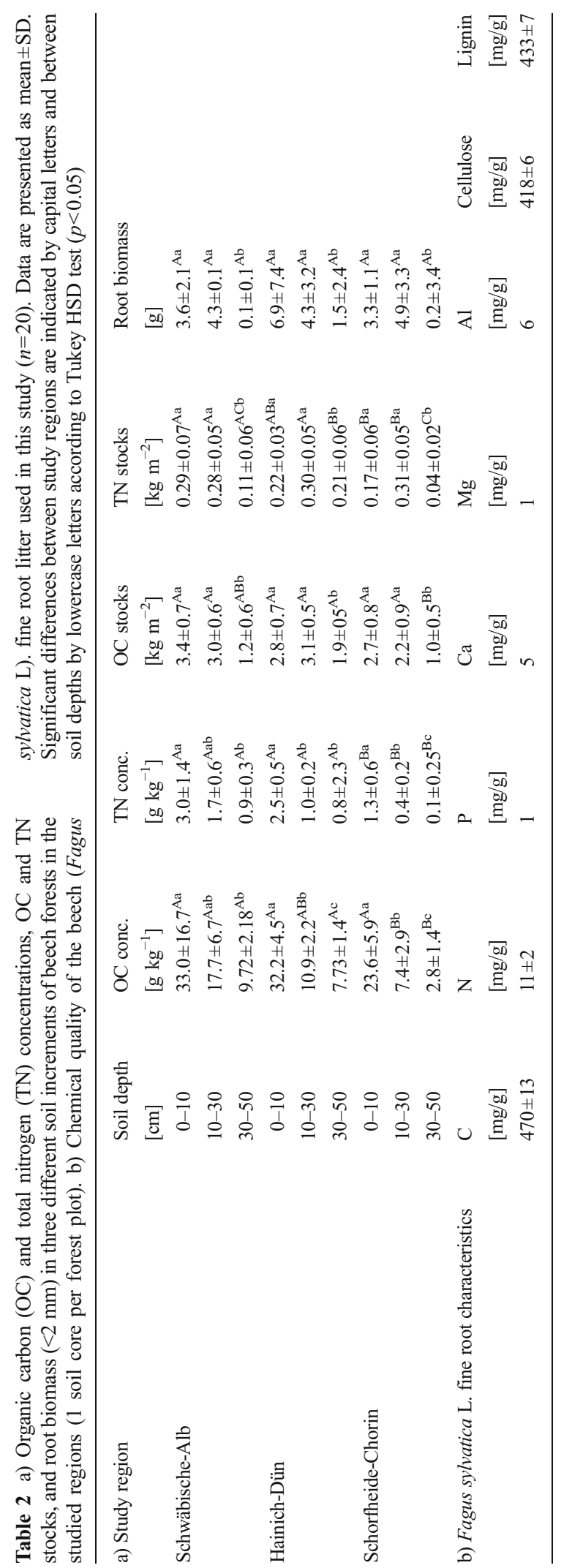

Table 3 Soil moisture and temperature over 2 years of decomposition, in all study regions at different soil depths (mean \pm SD). Soil temperature is expressed in ${ }^{\circ} \mathrm{C}$ and soil moisture is expressed in percentage of volumetric water content (\%VWC). $n=10$

\begin{tabular}{lllc}
\hline Study region & $\begin{array}{l}\text { Soil depth } \\
{[\mathrm{cm}]}\end{array}$ & $\begin{array}{l}\text { Soil temperature } \\
{\left[{ }^{\circ} \mathrm{C}\right]}\end{array}$ & $\begin{array}{l}\text { Soil moisture } \\
{[\%]}\end{array}$ \\
\hline Schwäbische-Alb & 10 & $6.3 \pm 3.8$ & $31 \pm 9$ \\
& 20 & $6.3 \pm 3.6$ & $30 . \pm 7$ \\
Hainich-Dün & 50 & $6.6 \pm 3.2$ & - \\
& 10 & $7.2 \pm 4.6$ & $29 \pm 5$ \\
& 20 & $7.4 \pm 4.4$ & $28 \pm 4$ \\
Schorfheide-Chorin & 10 & $6.6 \pm 5.2$ & - \\
& 20 & $9.0 \pm 5.3$ & $12 . \pm 2$ \\
& 50 & $7.6 \pm 4.7$ & - \\
\hline
\end{tabular}

the longest period ( 8 days per year) in comparison to the Schwäbische-Alb (6 days) and the Schorfheide-Chorin (4 days).

Root mass recovery, decomposition rates and $\mathrm{C}: \mathrm{N}$ ratio

After 2 years of decomposition on average for all depths $76 \pm 2 \%$ in Schorfheide-Chorin, $85 \pm 2 \%$ in Schwäbische-Alb, and $88 \pm 2 \%$ in Hainich-Dün of initial mass of beech fine root litter remained. The mass remaining did not differ significantly for the three depths sampled in the three regions for the majority of the collection times (Fig. 1), and thus our calculated decomposition rate-constants also did not vary with depth (Table 4). Only in the Hainich-Dün the mass remaining differed significantly between depths after 12 and 18 months of decomposition, and in the SchwäbischeAlb the amount of mass remaining differed among the 3 depths after 6 months of decomposition but not for the subsequent decomposition times (Fig. 1). Regional differences in the amount of fine root litter remaining after 2 years of decomposition were consistent over the three soil depths (Figs. 1, Fig. 2). Decomposition significantly increased the $\mathrm{C}: \mathrm{N}$ ratio of the fine root litter from 46 to 54 on average after 2 years (Fig. 3). The increase was similar across different soil depths (Fig. 3), and primarily driven by $\mathrm{N}$ loss as no major changes in the $\mathrm{C}$ concentrations were detected. After 2 years the $\mathrm{C}$ and $\mathrm{N}$ concentrations as well as the $\mathrm{C}: \mathrm{N}$ ratio of the decomposing fine roots were nearly constant throughout the soil profile, however the $\mathrm{C}$ concentrations of the roots decomposing at 20 and $35 \mathrm{~cm}$ soil depths were 


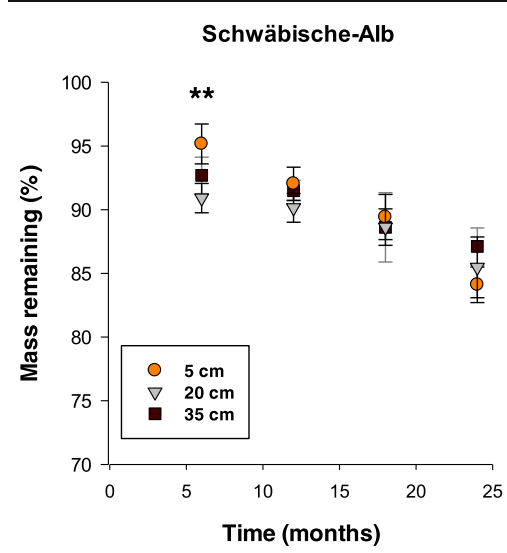

Fig. 1 Remaining fine root litter in beech forest plots of the a) Schwäbische-Alb, b) Hainich-Dün and c) Schorfheide-Chorin study regions. Beech fine roots were distributed in litterbags at three different soil depths $(5,20$ and $35 \mathrm{~cm})$ and harvested four

higher compared to the roots decomposing at $5 \mathrm{~cm}$ $(p<0.05)$ (Fig. 3).

\section{Discussion}

Similar fine root decomposition at different soil depths

Previous research proposed that litter decomposition rates would be highest in the topsoil and decrease in deeper soil horizons because microbial activities and substrate availability as well as relative variations in soil moisture and soil temperature decline with soil depth (e.g., more pronounced maximum temperature in the topsoil may increase decomposition in comparison to subsoil) (Fierer et al. 2003a; Jobbágy and Jackson 2000; Trumbore 2000; Weaver et al. 1935). In the studied forest plots the variability of both soil moisture and soil temperature slightly declined throughout the soil profile (Table 3), together with $\mathrm{OC}$ and $\mathrm{N}$ concentrations (Table 2). Herold et al. (2014) showed that extracellular enzyme activities significantly declined with soil depth in forest plots of the same study regions (Table 5 in supplementary material). Although these variables declined with soil depth we found that fine root
Hainich-Dün

Schorfheide-Chorin

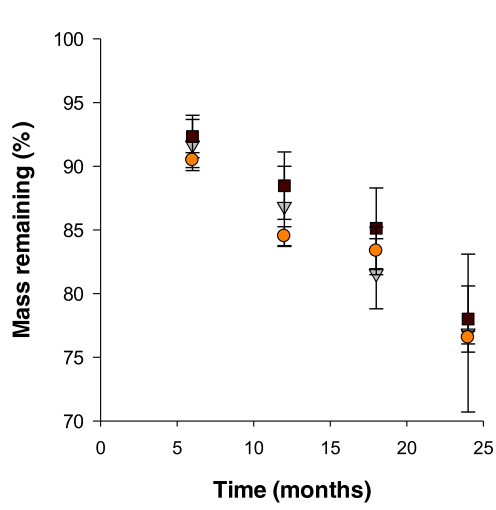

times in the first 2 years of decomposition. Data is presented as mean \pm SD. Statistical differences according to ANOVA and Tukey-Kramer HSD test results are presented as: * $(p<0.05), * *$ $(p<0.01)$ and $* * *(p<0.001)$

decomposition was nearly uniform through the forest soil horizons, except after 12 and 18 months in the Hainich-Dün and after 6 months in the SchwabischeAlb (Fig. 1). One reason explaining the similarity of the decomposition rates with soil depth, could be that while we observed that the variation of temperature and moisture declined with soil depth, their means were similar. Accordingly, lower winter temperatures in topsoils might balance lower summer temperatures of forest subsoils, leading to comparable decomposition rates in the topsoil and the subsoil. The same could be true for soil moisture, where greater variation in the topsoil (too dry or too wet) can be detrimental for decomposition (Chen et al. 2000).

The similarity of root decomposition at the three depths agreed with a study by Sanaullah et al. (2011). Sanaullah et al. (2011) showed that the amount of wheat root derived $\mathrm{C}$ and $\mathrm{N}$ remaining in the soil was similar in top- and subsoil horizons of a temporary grassland managed with a ley cropping system in southern France after 3 years of decomposition. Weaver (1947) also concluded that the rate of root decomposition did not show consistent differences at different soil depths throughout a prairie soil profile in North America. The recently published study by $\mathrm{Li}$ et al. (2015) also indi-

Table 4 Estimates of the decomposition rate-constant ( $k$-values) of fine roots at three different soil depths in 12 beech forest plots of the Schwäbische-Alb, HainichDün and Schorfheide-Chorin regions (mean $\pm \mathrm{SD})$

\begin{tabular}{llll}
\hline $\begin{array}{l}\text { Soil depth } \\
\mathrm{cm}\end{array}$ & $\begin{array}{l}\text { Schwäbische-Alb } \\
k \text {-values }\left[\mathrm{year}^{-1} \text { ] }\right.\end{array}$ & Hainich-Dün & Schorfheide-Chorin \\
\hline 5 & $0.09 \pm 0.02$ & $0.07 \pm 0.01$ & $0.13 \pm 0.01$ \\
20 & $0.07 \pm 0.02$ & $0.06 \pm 0.01$ & $0.13 \pm 0.04$ \\
35 & $0.08 \pm 0.01$ & $0.05 \pm 0.01$ & $0.12 \pm 0.02$ \\
\hline
\end{tabular}


Fig. 2 Remaining fine root litter in beech forest plots of the Schwäbische-Alb Hainich-Dün and Schorfheide-Chorin study regions during 2 years of decomposition. Data is presented as mean \pm SD calculated for all samples of one study region collected over the three soil depths for each sampling time. Statistical differences according ANOVA results and Tukey-Kramer HSD test are presented as: $*(p<0.05), * *$ $(p<0.01)$ and $* * *(p<0.001)$

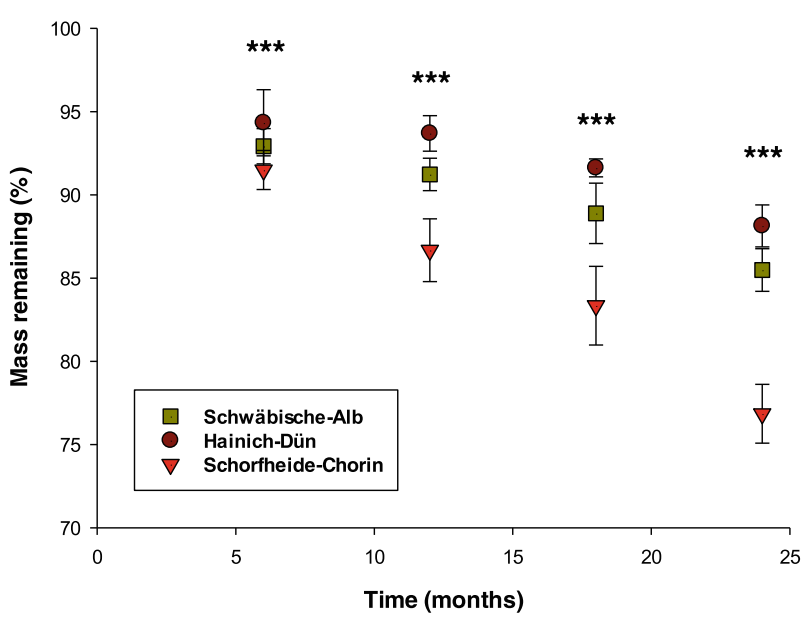

consequence of reduced resource availability and thus less microbial activity in deeper soil horizons (Fierer et al. 2003b; Herold et al. 2014), which we also observed in our study with decreased root biomass and nitrogen and OC concentrations with soil depth (Table 2). When inputs are increased, for example by adding a litterbag with new resources, microbial activity can also be stimulated in subsoils to achieve comparable decomposition to that in topsoils. Studies on lignin decomposition indicate that it depends on a continuous input of available energy and $\mathrm{C}$ sources, which enable the production of lignin degrading enzymes, and that it is hampered when bioavailable $\mathrm{C}$ becomes limited, i.e., during late decomposition stages (Klotzbücher et al.
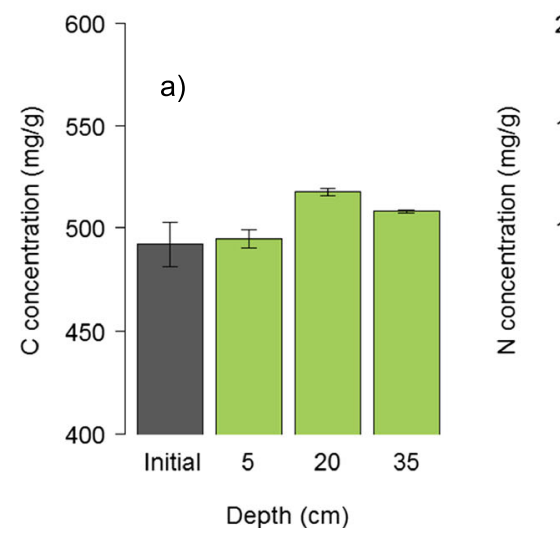

Fig. 3 Comparison of a) $\mathrm{C}$ concentrations, b) $\mathrm{N}$ concentrations and c) $\mathrm{C}: \mathrm{N}$ ratio of the initial standardized fine roots with the fine root litter after 2 years of decomposition at 5,10 and $35 \mathrm{~cm}$ soil depth. Statistical differences between the initial fine root litter

b)
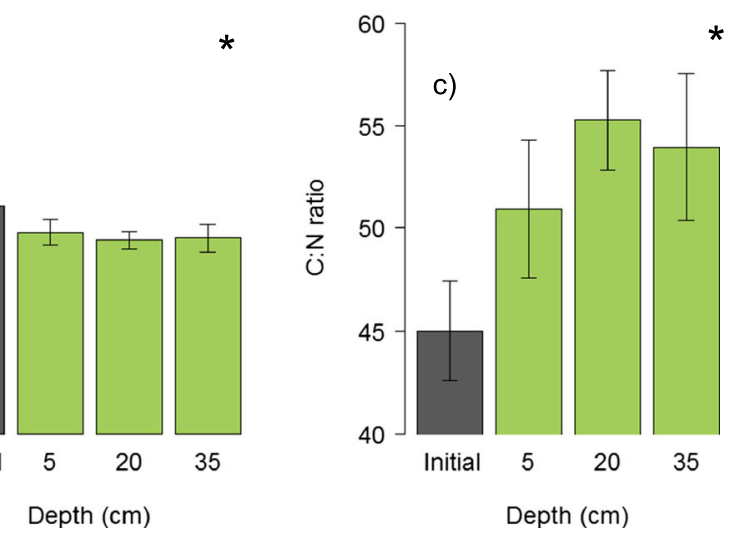

(grey) and the mean of the decomposing roots over all depths (green) are indicated as: $*(p<0.05), * *(p<0.01)$ and $* * *$ $(p<0.001)$ 
2011). Hence, it is possible that in later decomposition phases (after 2 years), the lower substrate inputs and nutrient resources in subsoils may hamper subsoil decomposition rates relative to topsoils. Longer-term decomposition experiments would be necessary to test this hypothesis.

It has been shown that the radiocarbon age of the more active, physicochemically unprotected $\mathrm{C}$ in the free light fraction only slightly increases with soil depth, while the less active fractions (C occluded in aggregates or in association with minerals) become older along the vertical soil profile (Schöning and Kögel-Knabner 2006; Schrumpf et al. 2013). Together with our results, this indicates that in both surface and deep soils the free light fraction, presumably derived from the breakdown of fine root litter -and aboveground litter in the topsoil, is preferentially decomposed at all soil depths.

Although after 2 years of decomposition the estimated decomposition rates ( $k$-values) for the whole time series were similar for all studied soil depths in all three study regions, in the Schwäbische-Alb study region the mass remaining after 6 months was highest in the topsoil. This may be related to colder temperatures in the topsoil during the winter months. Moreover, in the Hainich-Dün study region the decomposition of fine roots was observed to decline across the soil profile. An explanation for this is that the studied soils in this area (Luvisols) are characterized by a rich clay accumulation in the subsurface horizons, where soil water may stagnate for a longer time during wet periods, or dry out during the summer months. Hence, these conditions may reduce root decomposition across the soil profile. These exceptions indicate that the length of an experiment could lead to different outcomes of the influence of depth gradients on root decomposition rates within one study region.

After 2 years, the mass of the standardized beech fine root litter remaining was slightly higher than averages reported for other temperate tree species (Parton et al. 2007; Sun et al. 2013). These slower decomposition rates may reflect the higher amounts of lignin in Fagus sylvatica $\mathrm{L}$. roots compared to roots of other tree species (Hobbie et al. 2010). More lignified roots have a higher resistance to enzymatic attack and therefore tend to have slower decomposition rates than the less lignified counterparts (Berg 1984). In our experiment we used a litterbag mesh size of $100 \mu \mathrm{m}$, which enabled us to account only for microfaunal decomposition and excluded the larger soil decomposer community, which contributes to the mechanical breakdown of plant litter especially in topsoil layers. We cannot exclude that the decomposition absolute values might be different for roots decomposing in situ with different diameter sizes or ages (i.e., fine roots of 2 year-old samplings vs fine roots of adult trees or roots found at different soil depths), as was suggested by earlier studies (Dornbush et al. 2002, Goebel et al. 2010, Hishi 2007, Li et al. 2015). Therefore, the absolute amount of root mass that we recovered at different soil depths might be influenced by the set-up of the experiment. However, as litterbags and fine root litter were standardized, we can still compare the effects of soil properties on decomposition rates at different soil depths and in different regions.

Site effects on decomposition of fine roots

Although we observed no general trend with soil depth, the recovered fine root masses varied over all soil depths between the three regions (Fig. 2), supporting our second hypothesis. The same pattern of higher decomposition rates in the Schorfheide-Chorin followed by Schwäbische-Alb and Hainich-Dün was also found in a larger study aimed at investigating the factors controlling root decomposition in the topsoil of the same regions (Solly et al. 2014). In this larger scale experiment, exploring decomposition of standardized fine root litter in a range of forest types, soil temperature and moisture explained most of the regional variability of root decomposition in temperate forests. Although the Hainich-Dün study region has intermediate soil properties and climate, it has on average the lowest root decomposition rates. One explanation could be that in the Hainich-Dün the soils are on average frozen for a higher number of days in comparison to the other study regions (Solly et al. 2014). Previous studies have already shown that in soils with temperatures below $0{ }^{\circ} \mathrm{C}$ microbial activity declines (Dioumaeva et al. 2002; Mikan et al. 2002). Moreover, higher root decomposition rates in the Schorfheide-Chorin may result from a greater vertical water movement through the sand in this study region, which can increase the leaching of the soluble organic matter derived from the decomposing roots. Regional differences in the diversity of the soil biota, adapted to diverse edaphic factors including climate, soil texture and $\mathrm{pH}$ may also have played a role in determining the regional variability in fine root decomposition (Birkhofer et al. 2012, Thoms et al. 2010). 


\section{Conclusion}

Our results show that fine root decomposition in litterbags has a larger variability across regions than at different soil depths within a given site. Thus, a similar potential to decompose root derived $\mathrm{C}$ exists in both, surface and deep soils. Biological activity in different soil horizons would then be mainly limited by root litter input and thus the input of new substrates. Overall, rapid decomposition of litter along the soil profile is supported by the consistent young ages of $\mathrm{C}$ in unprotected fractions observed for different soil horizons in other studies. The increase in the age of bulk soil $\mathrm{C}$ with depth is likely to be more related to the mineral-stabilized $\mathrm{C}$, but further studies are required to test this hypothesis. Macroclimatic or other large-scale differences like parent material seem to be more important for initial stages of litter decomposition than changing conditions with soil depth, as regional differences in decomposition persisted for all studied soil depths.

Acknowledgments We thank Steffen Both, Jörg Hailer and Uta Schumacher for their help with the field work and technical organization. The authors acknowledge Beate Michalzik and Carlos Sierra for their valuable comments on the manuscript. We thank Theresa Klötzing for technical support, and Ines Hilke and Birgit Fröhlich for the $\mathrm{CN}$ analysis. Jakob Zscheischler for the mathematical and statistical help. We thank the managers of the three Exploratories, Kirsten Reichel-Jung, Swen Renner, Katrin Hartwich, Sonja Gockel, Kerstin Wiesner, and Martin Gorke for their work in maintaining the plot and project infrastructure; Christiane Fischer and Simone Pfeiffer for giving support through the central office, Michael Owonibi for managing the central data base, and Markus Fischer, Eduard Linsenmair, Dominik Hessenmöller, Jens Nieschulze, Daniel Prati, François Buscot, Ernst-Detlef Schulze, Wolfgang W. Weisser and the late Elisabeth Kalko for their role in setting up the Biodiversity Exploratories project. The work has been funded by the DFG Priority Program 1374 "Infrastructure-Biodiversity-Exploratories" (SCHR 1181/21) and the Max-Planck-Society. Field work permits were issued by the responsible state environmental offices of BadenWürttemberg, Thüringen, and Brandenburg (according to $\S 72$ BbgNatSchG). Emily Solly conducted this work as part of the International Max Planck Research School for Global Biogeochemical Cycles.

\section{References}

Berg B (1984) Decomposition of root litter and some factors regulating the process: long-term root litter decomposition in a Scots pine forest. Soil Biol Biochem 16:609-617. doi:10. 1016/0038-0717(84)90081-6
Birkhofer K, Schöning I, Alt F, Herold N, Klarner B, Maraun M, Marhan S, Oelmann Y, Wubet T, Yurkov A, Begerow D, Berner D, Buscot F, Daniel R, Diekötter T, Ehnes RB, Erdmann G, Fischer C, Foesel B, Groh J, Gutknecht J, Kandeler E, Lang C, Lohaus G, Meyer A, Nacke H, Näther A, Overmann J, Polle A, Pollierer MM, Scheu S, Schloter M, Schulze ED, Schulze W, Weinert J, Weisser WW, Wolters V, Schrumpf M (2012) General relationships between abiotic soil properties and soil biota across spatial scales and different land-Use types. PLoS ONE 7(8), e43292. doi:10.1371/ journal.pone.0043292

Brunner I, Godbold DL (2007) Tree roots in a changing world. J For Res 12:78-82. doi:10.1007/s10310-006-0261-4

Chen H, Harmon ME, Griffiths RP, Hicks W (2000) Effects of temperature and moisture on carbon respired from decomposing woody roots. For Ecol Manag 138:51-64. doi:10.1016/S0378-1127(00)00411-4

Dornbush ME, Isenhart TM, Raich JW (2002) Quantifying fineroot decomposition an alternative to buried litterbags. Ecology 83:2985-2990

Dioumaeva I, Trumbore S, Schuur EAG, Goulden ML, Litvak M, Hirsch AI (2002) Decomposition of peat from upland boreal forest: temperature dependence and sources of respired carbon. J Geophys Res: Atmos 107:8222. doi:10.1029/ $2001 \mathrm{jd} 000848$

Dixon RK, Solomon A, Brown S, Houghton R, Trexier M, Wisniewski J (1994) Carbon pools and flux of global forest ecosystems. Science 263:185-190

Fierer N, Allen AS, Schimel JP, Holden PA (2003a) Controls on microbial $\mathrm{CO} 2$ production: a comparison of surface and subsurface soil horizons. Glob Chang Biol 9:1322-1332

Fierer N, Schimel JP, Holden PA (2003b) Variations in microbial community composition through two soil depth profiles. Soil Biol Biochem 35:167-176. doi:10.1016/S0038-0717(02) 00251-1

Fischer M, Bossdorf $\mathrm{O}$, Gockel S, Hänsel $\mathrm{F}$, Hemp A, Hessenmöller D, Korte G, Nieschulze J, Pfeiffer S, Prati D, Renner S, Schöning I, Schumacher U, Wells K, Buscot F, Kalko EKV, Linsenmair KE, Schulze ED, Weisser WW (2010) Implementing large-scale and long-term functional biodiversity research: the biodiversity exploratories. Basic Appl Ecol 11:473-485. doi:10.1016/j.baae.2010.07.009

Fontaine S, Barot S, Barre P, Bdioui N, Mary B, Rumpel C (2007) Stability of organic carbon in deep soil layers controlled by fresh carbon supply. Nature 450:277-280, http:// www.nature.com/nature/journal/v450/n7167/suppinfo/ nature06275_S1.html

Gill R, Burke I (2002) Influence of soil depth on the decomposition of bouteloua gracilis roots in the shortgrass steppe. Plant Soil 241:233-242. doi:10.1023/a:1016146805542

Goebel M, Hobbie SE, Bulaj B, Zadworny M, Archibald DD, Oleksyn J, Reich PB, Eissenstat D (2010) Decomposition of the finest root branching orders: linking belowground dynamics to fine-root function and structure. Ecol Monogr 81: 89-102

Grüneberg E, Schöning I, Kalko EKV, Weisser WW (2010) Regional organic carbon stock variability: a comparison between depth increments and soil horizons. Geoderma 155:426-433. doi:10.1016/j.geoderma.2010. 01.002 
Handa IT, Aerts R, Berendse F, Berg MP, Bruder A, Butenschoen O, Chauvet E, Gessner MO, Jabiol J, Makkonen M, McKie BG, Malmqvist B, Peeters ETHM, Scheu S, Schmid B, van Ruijven J, Vos VCA, Hattenschwiler S (2014) Consequences of biodiversity loss for litter decomposition across biomes. Nature 509:218-221. doi:10.1038/nature13247

Heim A, Frey B (2004) Early stage litter decomposition rates for Swiss forests. Biogeochemistry 70:299-313. doi:10.1007/ s10533-003-0844-5

Heiri O, Lotter AF, Lemcke G (2001) Loss on ignition as a method for estimating organic and carbonate content in sediments: reproducibility and comparability of results. J Paleolimnol 25:101-110

Herold N, Schöning I, Berner D, Haslwimmer H, Kandeler E, Michalzik B, Schrumpf M (2014) Vertical gradients of potential enzyme activities in soil profiles of European beech, Norway spruce and Scots pine dominated forest sites. Pedobiologia 7:181-189

Hishi T (2007) Heterogeneity of individual roots within the fine root architecture: casual links between physiological and ecosystem functions. J For Res 12:126-133

Hobbie S, Oleksyn J, Eissenstat D, Reich P (2010) Fine root decomposition rates do not mirror those of leaf litter among temperate tree species. Oecologia 162:505-513. doi:10. 1007/s00442-009-1479-6

Jobbágy EG, Jackson RB (2000) The vertical distribution of soil organic carbon and its relation to climate and vegetation. Ecol Appl 10:423-436. doi:10.2307/2641104

Klotzbücher T, Kaiser K, Guggenberger G, Gatzek C, Kalbitz K (2011) A new conceptual model for the fate of lignin in decomposing plant litter. Ecology 92:1052-1062. doi:10. 1890/10-1307.1

Li A, Fahey TJ, Pawlowska TE, Fisk MC, Burtis J (2015) Fine root decomposition, nutrient mobilization and fungal communities in a pine forest ecosystem. Soil Biol Biochem 83: 76-83

Mendez-Millan M, Dignac MF, Rumpel C, Rasse DP, Derenne S (2010) Molecular dynamics of shoot vs. root biomarkers in an agricultural soil estimated by natural abundance $13 \mathrm{C}$ labelling. Soil Biol Biochem 42:169-177. doi:10.1016/j. soilbio.2009.10.010

Mikan CJ, Schimel JP, Doyle AP (2002) Temperature controls of microbial respiration in arctic tundra soils above and below freezing. Soil Biol Biochem 34:1785-1795. doi:10.1016/ S0038-0717(02)00168-2

Olson JS (1963) Energy storage and the balance of producers and decomposers in ecological systems. Ecology 44:322-331

Parton W, Silver WL, Burke IC, Grassens L, Harmon ME, Currie WS, King JY, Adair EC, Brandt LA, Hart SC, Fasth B (2007) Global-scale similarities in nitrogen release patterns during long-term decomposition. Science 315:361-364. doi:10. 1126/science. 1134853

Paul EA, Follett RF, Leavitt SW, Halvorson A, Peterson GA, Lyon DJ (1997) Radiocarbon dating for determination of soil organic matter pool sizes and dynamics. Soil Sci Soc Am J 61: $1058-1067$. doi: $10.2136 /$ s s s a j 1997 . $03615995006100040011 x$

Qualls RG, Haines BL (1992) Biodegradability of dissolved organic matter in forest throughfall, soil solution, and stream water. Soil Sci Soc Am J 56:578-586
Raessler M, Rothe J, Hilke I (2005) Accurate determination of Cd, $\mathrm{Cr}, \mathrm{Cu}$ and $\mathrm{Ni}$ in woodlice and their skins - is moulting a means of detoxification? Sci Total Environ 337:83-90. doi: 10.1016/j.scitotenv.2004.07.008

Rasse DP, Rumpel C, Dignac MF (2005) Is soil carbon mostly root carbon? Mechanisms for a specific stabilisation. Plant Soil 269:341-356. doi:10.1007/s11104-004-0907-y

Rovira P, Ramón Vallejo V (2002) Mineralization of carbon and nitrogen from plant debris, as affected by debris size and depth of burial. Soil Biol Biochem 34:327-339. doi:10.1016/ S0038-0717(01)00186-9

Rumpel C, Kögel-Knabner I (2011) Deep soil organic matter-a key but poorly understood component of terrestrial C cycle. Plant Soil 338:143-158. doi:10.1007/ s11104-010-0391-5

Sanaullah M, Chabbi A, Leifeld J, Bardoux G, Billou D, Rumpel C (2011) Decomposition and stabilization of root litter in topand subsoil horizons: what is the difference? Plant Soil 338: 127-141. doi:10.1007/s11104-010-0554-4

Schlesinger WH (1997) Biogeochemistry: an analysis of global change. Academic Press, San Diego

Schöning I, Kögel-Knabner I (2006) Chemical composition of young and old carbon pools throughout Cambisol and Luvisol profiles under forests. Soil Biol Biochem 38:24112424. doi:10.1016/j.soilbio.2006.03.005

Schrumpf M, Kaiser K, Guggenberger G, Persson T, KögelKnabner I, Schulze ED (2013) Storage and stability of organic carbon in soils as related to depth, occlusion within aggregates, and attachment to minerals. Biogeosciences 10: 1675-1691. doi:10.5194/bg-10-1675-2013

Solly EF, Schöning I, Boch S, Kandeler E, Marhan S, Michalzik B, Müller J, Zscheischler J, Trumbore SE, Schrumpf M (2014) Factors controlling decomposition rates of fine root litter in temperate forests and grasslands. Plant Soil 382:203218. doi:10.1007/s11104-014-2151-4

Sun T, Mao Z, Dong L, Hou L, Song Y, Wang X (2013) Further evidence for slow decomposition of very fine roots using two methods: litterbags and intact cores. Plant Soil 366:633-646. doi:10.1007/s11104-012-1457-3

Thoms C, Gattinger A, Jacob M, Thomas FM, Gleixner G (2010) Direct and Indirect efects of tree diversity drive soil microbial diversity in temperate deciduous forest. Soil Biol Biochem 42:1558-1565

Trumbore S (2000) Age of soil organic matter and soil respiration: radiocarbon constraints on belowground $\mathrm{C}$ dynamics. Ecol Appl 10:399-411

Trumbore S (2009) Radiocarbon and soil carbon dynamics. Annu Rev Earth Planet Sci 37:47-66

van Huysen TL, Harmon ME, Perakis SS, Chen H (2013) Decomposition and nitrogen dynamics of 15 N-labeled leaf, root, and twig litter in temperate coniferous forests. Oecologia 173:1563-1573

Weaver JE (1947) Rate of decomposition of roots and rhizomes of certain range grasses in undisturbed prairie soil. Ecology 28: $221-240$

Weaver JE, Hougen V, Weldon M (1935) Relation of root distribution to organic matter in prairie soil. Bot Gaz 96:389-420

Yang H, Yan R, Chen H, Zheng C, Lee DH, Liang DT (2005) Indepth investigation of biomass pyrolysis based on three major components: hemicellulose, cellulose and lignin. Energy Fuel 20:388-393. doi:10.1021/ef0580117 